Informatika i sistemy upravleniya. - 2019. - No. 4(62). - P. 132-138.

Kudinov Yu. I., Duvanov E. S., Ivanov A.G., Durgarian I.S., Paschenko A.F., Pashchenko F.F. (pif-70@yandex.ru)

Institute of Control Sciences V. A. Trapeznikov

\title{
DIRECT SYNTHESIS METHOD OF DISCRETE REGULATOR
}

The procedure of direct synthesis method of the discrete regulator, providing restrictions on quality control indicators with use of the software complexes Matlab and Simulink, is considered. The algorithm of synthesis of the discrete transfer function of the closed system of the second order is offered.

Keywords: transition process, discrete regulator, continuous regulator, discrete transfer function, direct synthesis method: Matlab, Simulink.

DOI: 10.22250/isu.2019.62.132-138

For citation:

Kudinov Yu. I., Duvanov E. S., Ivanov A.G., Durgarian I.S., Paschenko A.F., Pashchenko F.F. DIRECT SYNTHESIS METHOD OF DISCRETE REGULATOR // Informatika i sistemy upravleniya. - 2019. - No. 4(62). - P. 132-138. 